\title{
Twenty-week Brain Vascularity by Transvaginal 3D HDlive Flow
}

\section{${ }^{1-5}$ Ritsuko K Pooh}

\section{ABSTRACT}

Recent advances of three-dimensional (3D) Doppler application is HDlive flow providing a realistic rendering of fine peripheral blood vessels, such as vascularity of the lung, brain, and eyeballs. The picture of the month demonstrates an obliquesagittal view of the brain vascularity. Flow imaging can add both angiostructural and functional information to structural findings of normal and abnormal central nervous system.

Keywords: Brain, Circulation, Fetus, HDlive flow, 3D Ultrasound.

How to cite this article: Pooh RK. 20-week Brain Vascularity by Transvaginal 3D HDlive Flow. Donald School J Ultrasound Obstet Gynecol 2016;10(3):203-204.

\section{Source of support: Nil}

\section{Conflict of interest: None}

\section{INTRODUCTION}

HDlive flow ${ }^{1-5}$ is a recent three-dimensional (3D) Doppler application and this technology generates a $3 \mathrm{D}$ view of the blood flow and providing a realistic rendering of fine peripheral blood vessels, such as vascularity of the lung, brain, and eyeballs. In the fetal period, cerebral vasogenesis occurs with cerebral development. Brain circulation was visualized by two-dimensional (2D) ultrasound ${ }^{6,7}$ in 1993-1994 and the author succeeded in visualizing early brain circulation by 3D ultrasound. ${ }^{8}$ HDlive flow depicts furthermore realistic 3D angiostructure by transvaginal 3D HDlive flow, shown in Figure 1. Oblique-sagittal view

\footnotetext{
${ }^{1}$ President, ${ }^{2}$ Honorary Professor, ${ }^{3}$ Professor, ${ }^{4}$ Executive Director and Asia Oceania Regional Director ${ }^{5}$ National Director

${ }^{1}$ Clinical Research Institute of Fetal Medicine PMC Osaka Japan

${ }^{2}$ Pirogov Russian National Research Medical University Moscow Russia

${ }^{3}$ Department of Health Science, Dubrovnik International University, Dubrovnik, Croatia

4,5 lan Donald Inter-University School of Medical Ultrasound Dubrovnik, Croatia

Corresponding Author: Ritsuko K Pooh, Professor, Department of Health Science, Dubrovnik International University, Dubrovnik Croatia, e-mail: rkpooh@me.com
}

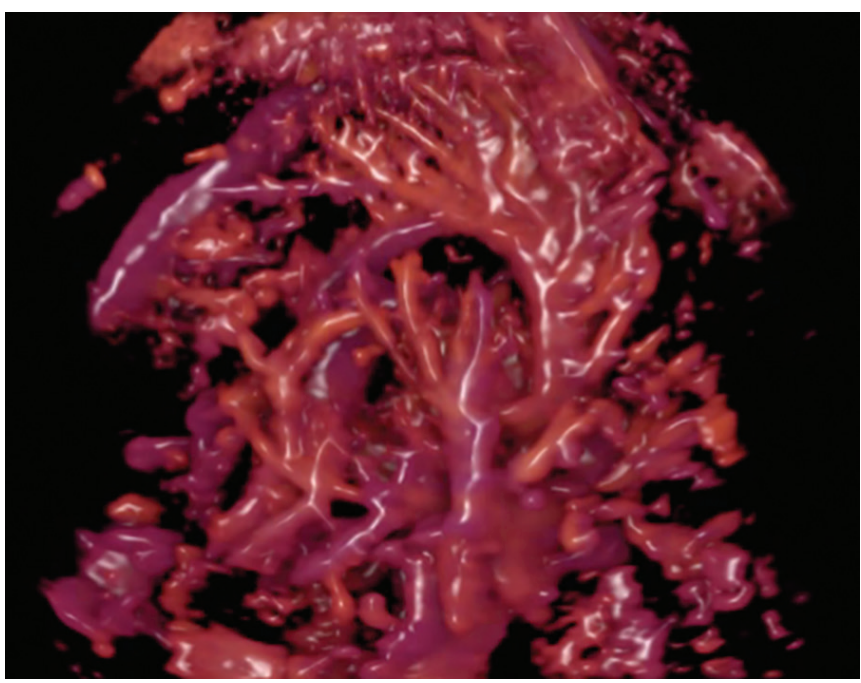

Fig. 1: Oblique-sagittal view of brain vascularity at 20 weeks of gestation by transvaginal 3D HDlive flow Internal carotid artery, anterior cerebral artery, pericallosal artery and branches, superior sagittal sinus, lenticulostriate arteries are well demonstrated

of the brain vascularity is demonstrated and internal carotid artery, anterior cerebral artery, pericallosal artery and branches, superior sagittal sinus, lenticulostriate arteries are well demonstrated. Thus, by using HDlive flow, each brain vessel is clearly depicted. Flow imaging can add both angiostructural and functional information to structural findings of normal and abnormal central nervous system.

\section{REFERENCES}

1. Pooh RK. First trimester scan by 3D, 3D HDlive and HDlive silhouette/flow ultrasound imaging. Donald School J Ultrasound Obstet Gynecol 2015 Oct-Dec;9(4):361-371.

2. Pooh RK. 'See-through fashion' in prenatal diagnostic imaging. Donald School J Ultrasound Obstet Gynecol 2015; 9(2):111.

3. Pooh RK. Brand new technology of HDlive silhouette and HDlive flow images. In: Pooh RK, Kurjak A, editors. Donald School Atlas of advanced ultrasound in obstetrics and gynecology. New Delhi: Jaypee Brothers Medical Publishers (P) Ltd.; 2015. p. 1-39.

4. Pooh RK. A new field of fetal sono-ophthalmology by 3D HDlive silhouette and flow. Donald School J Ultrasound Obstet Gynecol 2015 Jul-Sep;9(3):221-222.

5. Pooh RK. 13-week pulmonary sonoangiogram by 3D HDlive flow. Donald School J Ultrasound Obstet Gynecol 2015 Oct-Dec;9(4):355-356. 
6. Kurjak A, Zudenigo D, Predanic M, Kupesic S. Recent advances in the Doppler study of early fetomaternal circulation. J Perinat Med 1993;21(6):419-439.

7. Kurjak A, Schulman H, Predanic A, Predanic M, Kupesic S, Zalud I. Fetal choroid plexus vascularization assessed by color flow ultrasonography. J Ultrasound Med 1994 Nov; 13(11):841-844.

8. Pooh RK, Aono T. Transvaginal power Doppler angiography of the fetal brain. Ultrasound Obstet Gynecol 1996 Dec; $8(6): 417-421$. 